\title{
Victor Klemperer: a linguagem do mal e a nazificação da sociedade alemã
}

\author{
Victor Klemperer: the language of evil and \\ the nazification of German society
}

Marcelo Leandro dos Santos ${ }^{1}$

\begin{abstract}
Resumo: Este artigo contextualiza o nazismo como projeto de degradação da multiplicidade humana a partir da instrumentalização da língua alemã e consequentemente da linguagem como experiência humana. Tal contextualização se inicia apresentando os projetos amplamente conhecidos do nazismo, que se dão à sombra de Auschwitz, para, em seguida, partir à análise das observações de Victor Klemperer sobre a aplicação da LTI (Lingua Tertii Imperii) na sociedade alemã no período que envolveu o entreguerras e o final da Segunda Guerra Mundial, precisamente na cidade de Dresden, onde Klemperer viveu e repensou sua condição judaica. Por meio do uso estratégico da linguagem, o nazismo interveio nos hábitos da sociedade alemã, o que implicou a adesão popular à ideologia do Terceiro Reich, bem como provocou a legitimação da reprodução do mal naquela sociedade, enquanto projeto pervertido de cidadania. Disso resulta uma compreensão biopolítica da linguagem, na medida em que se reconhece o nazismo como doutrina do fanatismo.
\end{abstract}

Palavras-chave: nazismo, linguagem, biopolítica, cotidiano, fanatismo, condição judaica.

\begin{abstract}
This paper contextualizes Nazism as a project of degradation of human multiplicity from the instrumentalization of the German language and consequently of language as a human experience. Such contextualization begins by presenting the widely known projects of Nazism, which are given in the shadow of Auschwitz, and then begin with the analysis of the observations of Victor Klemperer on the application of LTI (Lingua Tertii Imperii) in German society in the period that involved between the wars and the end of World War II, precisely in the city of Dresden, where Klemperer lived and rethought his Jewish condition. Through strategic use of language, Nazism intervened in the habits of German society, which implied popularly adherence to the ideology of the Third Reich, as well as provoked the legitimation of the reproduction of evil in that society as a perverted project of citizenship. This results in a biopolitical understanding of language, insofar as Nazism is recognized as a doctrine of fanaticism.
\end{abstract}

Keywords: Nazism, language, biopolitics, daily life, fanaticism, Jewish condition.

\footnotetext{
${ }^{1}$ Professor na Universidade do Vale do Taquari (Univates), < marcelolean.s@gmail.com>. O presente artigo integra as atividades previstas para o estágio pós-doutoral no Programa de Pós-Graduação em Filosofia da Pontifícia Universidade Católica do Rio Grande do Sul (PUCRS), realizado no período de 2017-2018 sob supervisão do Prof. Dr. Ricardo Timm de Souza.
} 


\section{Introdução}

Em 1947, dois anos após o final da Segunda Guerra Mundial, iniciase a publicação de escritos sobre a guerra pela perspectiva daqueles que a sofreram. Pode-se citar, entre os livros mais conhecidos e comentados, Se questo è un uomo, de Primo Levi, o qual se tornou referência para uma vertente intelectual que estava ainda a emergir: a literatura do testemunho. Essa obra inaugural de Levi, assim como boa parte de seus escritos posteriores, mostra-se singular por descrever com fortes relatos não apenas a experiência de um sobrevivente de Auschwitz, mas, sobretudo, pelo fato de que, subjacente à sua dimensão memorialística, pulsa na escrita o compromisso de apresentar uma intensa e perturbadora reflexão ética sobre o preço moral da sobrevivência humana.

Dentre as ruínas da Segunda Guerra restou também a consciência da defasagem dos grandes discursos sobre a moral, uma vez que o sobrevivente, não invariavelmente, passou a considerar a si próprio como suspeito da decadência da vida por vir, que acabaria sendo vivida, então, desde este ponto, à sombra de certa indignidade, a qual não se extinguiria com o fim da guerra. Para o pragmatismo do mundo positivo o pós-guerra é o tempo (pós)-traumático de reerguer os escombros. No entanto, nem sempre as personagens que restaram são capazes de reerguer a si mesmas. Os fantasmas do tempo não costumam ser indiferentes com aqueles espíritos humanos que não se contentam com versões pragmáticas da vida. Sem a intenção de produzir qualquer tipo de juízo a esse respeito, vale lembrar que em função desse cenário o suicídio assombrou as vidas de muitos sobreviventes, como parece ter sido o destino de Levi, mesmo considerando que as circunstâncias de sua morte em 1987 ainda não foram completamente esclarecidas, dividindo as opiniões de seus familiares e biógrafos.

Além de Primo Levi, tantos outros buscaram expressar suas experiências de sobrevivente. Imre Kertész, Simon Wiesenthal, Jean Améry, Paul Celan, Jorge Semprún, Ruth Klüger, Elie Wiesel estão entre eles. Muitos desses escritos pertencem ao contexto da Shoah, termo adotado por Wiesel com a intenção de elucidar o clima de derrota irrecuperável para a humanidade e, ao mesmo tempo, a construção de um aprendizado a respeito dessa derrota, o qual pudesse ser capaz de projetar o revigoramento da misericórdia entre os seres humanos; tarefa para a 
qual a memória exerce papel fundamental, obviamente. Quase a totalidade desse esforço ético-reflexivo se dá à sombra de Auschwitz, provavelmente em função de este ter sido o Lager $^{2}$ melhor organizado para a produção da degradação do espírito humano.

Sim, a degradação era a meta do projeto nazista, cuja determinação nunca se contentou em simplesmente matar. Matar - ato que a humanidade conhece tão bem e que sempre foi meio de guerra para qualquer exército - em mãos nazistas se tornou auto de fé. Como escreveu Paul Celan em "Fuga da morte": "[...] a morte é um dos mestres da Alemanha seu olho é azul [...]"3. Sem Deus, mas com o Führer, o Lager expressava a concretização do ideal nazista: degradar a multiplicidade humana e sobre essa degradação edificar a farsa da superioridade da raça. Nesse ideal está implicada, em múltiplos procedimentos oficiais e extraoficiais, a devoração da diferença, a qual os povos ciganos expressaram em seu idioma por Porajmos, termo que, respeitadas as diferenças culturais, pode ser considerado correlato a Shoa $h^{4}$.

Estudos atuais sobre biopolítica não hesitam em considerar o Lager como o lugar por excelência da produção dessa farsa da superioridade racial e modelo para outras farsas atuais e por vir. Nesse sentido, Antonio Negri considera Primo Levi uma "testemunha do monstro" no Lager, tal como Frantz Fanon nas guerras de libertação anticoloniais, Jean Genet na causa palestina e tantos outros em diferentes contextos biopolíticos ${ }^{5}$.

\footnotetext{
${ }^{2}$ Forma diminutiva da palavra alemã Arbeitslager, com a qual cinicamente os nazistas chamavam seus campos de concentração, que, à diferença de certos campos de prisioneiros - como o campo de Modena, na Itália fascista, onde Primo Levi estava antes de ser enviado para Auschwitz em 1944 eram, na verdade, campos onde a exploração do trabalho escravo servia de mão-de-obra base em complexos industriais. A partir de um uso retórico da noção moralista inscrita no pórtico de Auschwitz, a saber, "o trabalho liberta" [Arbeit macht frei], a expressão Arbeitslager pressupunha certa noção positivista com a pretensão de justificar moralmente sua existência. A respeito do uso pervertido do sentido do trabalho em Auschwitz e seu status de referencial simbólico da ideologia nazista, cf. SANTOS, Marcelo Leandro dos. "Primo Levi: escrever e sobreviver após Auschwitz". In: OLIVEIRA, Rejane Pivetta de (org.). Literatura para pensar e intervir no mundo. Porto Alegre: Ed. Uniritter, 2013, p. 125-147.

${ }^{3}$ In GUINSBURG, J.; TAVARES, Z. (orgs.). Quatro mil anos de poesia. Tradução de Modesto Carone. São Paulo: Perspectiva, 1969, p. 270-271.

${ }^{4}$ É interessante observar que a metáfora da devoração também está presente nos livros sagrados da tradição judaico-cristã que tematizam a Shoah, como, por exemplo, em Dt, 31:17.

${ }^{5}$ NEGRI, Antonio. "El monstruo político. Vida desnuda y potencia”. In: GIORGI, Gabriel; RODRÍGUEZ, Fermín (comps.). Ensayos sobre biopolítica: excesos de vida. Buenos Aires: Paidós, 2007, p. 102.
} 
Para além da posição dos problemas legítimos que orbitam o Lager, os quais se iniciam com os testemunhos memorialísticos e também reflexivos dos sobreviventes contextualizados pela Shoah - o que implica uma análise interdisciplinar dos efeitos do trauma ${ }^{6}$ - e são ampliados na atualidade para as discussões complexas da biopolítica, há também contribuições oriundas de perspectivas que se deslocam do Lager, sendo estas, no sentido literal do termo, excêntricas.

Assim, o presente texto contextualizará temas já bastante conhecidos que visam discutir o projeto nazista de degradação do espírito humano, porém, pela perspectiva de um sobrevivente judeu que nunca esteve em um Lager, tendo presenciado e percebido os elementos do projeto nazista no cotidiano urbano de Dresden, cidade alemã de história riquíssima e que, nos últimos momentos da Segunda Guerra, foi arrasada por um dos mais severos bombardeios protagonizados pelos Aliados ${ }^{7}$. Esse sobrevivente - também uma testemunha do monstro caso se queira ampliar a observação de Negri - é Victor Klemperer, filólogo, pedagogo e historiador da literatura; um intelectual de sólida formação erudita.

Nascido em 1881, filho de um rabino, Victor Klemperer se converteu ao luteranismo aos 24 anos de idade. A conversão naquele momento (1903) era muito comum como decisão que visava propósitos sociais. Klemperer, em especial, tinha uma visão nacionalista, e em função disso acreditava ser interessante declarar-se luterano. Aliás, consta que seu pai teria sido um rabino não ortodoxo, possivelmente simpatizante de ideias mais progressistas, condição que talvez tenha contribuído para que Victor e alguns de seus irmãos não seguissem o judaísmo e, em troca, cultivassem uma visão agnóstica da vida espiritual.

Na Primeira Guerra Klemperer serviu como voluntário (1915-1916) e na seção de imprensa do governo militar alemão (1916-1918). Enfim, era um homem aparentemente desconectado do espírito judeu, o que alguns chamam de "judeu sem judaísmo". Essa experiência peculiar de não mais

\footnotetext{
${ }^{6}$ Para uma abordagem específica, aprofundada e interdisciplinar, recomenda-se a leitura de NESTROVSKI, Arthur; SELIGMANN-SILVA, Márcio (orgs.). Catástrofe e representação. São Paulo: Escuta, 2000.

${ }^{7}$ Para uma contextualização dos bombardeios a Dresden, inclusive situando Victor e Eva Klemperer entre suas personagens, recomenda-se a seguinte obra que ilustra o panorama histórico desta peculiar cidade alemã, considerada a Florença do Elba em função de sua importância cultural: TAYLOR, Frederick. Dresden: Terça-feira, 13 de fevereiro de 1945. Tradução de Vítor Paolozzi. Rio de Janeiro: Record, 2011.
} 
sentir-se um judeu foi recorrente entre judeus alemães no período da Primeira Guerra. No caso de Klemperer, experiência provavelmente acentuada pelo fato de estar casado desde 1906 com uma alemã não judia, a pianista Eva Klemperer (née Schlemmer). Klemperer trabalhou como jornalista e escritor em algumas cidades alemãs. Terminada a Primeira Guerra, em 1918, retornou a Leipzig.

Portanto, naquele momento, ele se sentia completamente integrado como cidadão alemão, orgulhoso de suas condecorações como combatente e socialmente articulado como um luterano casado com uma alemã, que posteriormente seria designada "ariana" ${ }^{8}$ pelas Leis de Nuremberg. Em 1920, torna-se professor titular da Escola Técnica Superior de Dresden. Enfim, estabelece-se profissionalmente. Concentra seus estudos na história do romance francês, sendo inclusive classificado pela Enciclopédia Brockhaus como profundo conhecedor da literatura francesa. Em 1935, após a subida de Hitler ao poder, perde seu cargo e sua casa e passa a morar com a esposa entre uma e outra Judenhaus, literalmente a casa conjunta para os judeus que viviam aquilo que era chamado pelos nazistas de casamento misto.

O fato de sua companheira Eva não tê-lo abandonado foi uma espécie de salvo-conduto, embora sempre provisório, que por algumas vezes evitou que Victor fosse enviado ao Lager. Bastaria a ela separar-se (sofria forte pressão social para isso) e não necessitaria mais passar pelas incontáveis restrições que passou ao lado do marido. A perversidade nazista, apoiada em onipresente campanha publicitária, impunha dispositivos dentro da vida privada dos casais como constante teste para que, com um exercício falacioso, fosse enxergada no judeu a identidade definitiva de toda maldição primordial e, assim, moralmente - pela visão hipócrita daquela sociedade ${ }^{9}$ - justificado o seu eventual abandono. Mas

\footnotetext{
${ }^{8}$ Na primeira vez no texto esse termo aparece entre aspas com a finalidade de causar estranheza ao leitor, sustentando a expectativa por uma reflexão sobre a aberração jurídico-política que o ato oficial de adjetivar arbitrariamente a vida singular dos cidadãos representa. Doravante, as aspas não mais aparecerão para esse termo, seguindo exemplo literário de algumas obras que retratam o período.

${ }^{9} \mathrm{~A}$ associação do adjetivo hipócrita à referida sociedade pode parecer uma atribuição peremptória e, nesse sentido, contraditória na medida em que se considera a manipulação que a mesma sofrera no período. Ou seja, se alguém é manipulado não tem consciência da hipocrisia de seus atos. Contudo, tal associação encontra algum sentido quando se pensa no contexto das relações sociais do casal Klemperer, cujo círculo de amizades pertencia ao universo intelectual, ao qual se poderia atribuir um domínio maior da compreensão contextual da realidade. De qualquer modo, esta também seria uma posição paradoxal, uma vez que a confiança excessiva no esclarecimento é um dos fundos falsos da
} 
Eva não poderia ser considerada uma mulher da multidão, na medida em que não se mostrava suscetível a teorizações genéricas a respeito do comportamento humano. Sua personalidade fora esculpida com convicção e fibra, o que só fazia fortalecer cada vez mais os laços de admiração e respeito que seu companheiro nutria por ela.

Com a proibição do acesso a bibliotecas imposta aos judeus, Eva eventualmente colocava-se em risco retirando livros para que seu marido pudesse ter alguns poucos momentos de leitura após dias inteiros de trabalhos pesados e cansativos aos quais estava condenado. Ela também teve papel fundamental em todos os momentos em que, com a cumplicidade de uma amiga ariana do casal, ajudava a esconder os escritos de Victor - seus diários e suas reflexões durante o período do regime nazista. Ler e escrever estavam expressamente proibidos aos judeus, somando-se a tantas outras medidas absurdas, como, por exemplo, a captura e o consequente extermínio dos animais domésticos que conviviam com eles. O casal Klemperer, que não tinha filhos, mas tinha um gato e um canário, não escapou dessa atrocidade. Essa perseguição nazista, em especial, demonstra o interesse político do bioterror, uma vez que visava exclusivamente desestabilizar por completo a vida doméstica. Os nazistas se preocupavam em desintegrar todo e qualquer laço afetivo produzido na intimidade do lar judeu. Eles não admitiam que a Judenhaus fosse, de fato, uma casa, pois na visão deles, o judeu sequer era digno do habitar como experiência humana. Nesse sentido, Judenhaus é uma espécie de palavra-monstro, como tantas outras que Klemperer anotaria em seus diários.

Nessas condições, que fazem transcender toda possibilidade de candura, o amor de Eva se expressou como sopro vital para que seu companheiro tivesse um pouco mais do que a simples sobrevivência e pudesse, com acesso clandestino a livros e anotações, manter acesa a chama intelectual que antes compunha a integralidade de sua vida. Essa 
condição foi descrita por Klemperer como sendo sua "vara de equilibrista"10. A postura de Eva é um belo ensinamento de que a vida íntegra - a vida reta que inspira as reflexões sobre a moral desde a Antiguidade - deveria pressupor não apenas o cultivo das virtudes entronizadas por Aristóteles (lealdade, coragem e generosidade, por exemplo), mas também disposições reflexivas nada convencionais e que, justamente por essa razão, não são claras e acessíveis ao senso comum. Entre essas disposições não convencionais está a resiliência subversiva, a qual Eva teve força e sabedoria para demonstrar. Klemperer reconhece o heroísmo original de sua esposa, sempre fazendo questão de registrá-lo ao longo de seus escritos, os quais não existiriam sem Eva.

Como filólogo, Klemperer potencializou suas observações sobre as providências do governo nazista juntamente com o comportamento dos cidadãos com os quais tinha contato. Ele sustentou a suspeita de que estava surgindo uma língua própria do nazismo, uma espécie de instrumentalização do idioma alemão cujo objetivo era a manipulação e engajamento das massas. Essa suspeita foi por ele denominada de Lingua Tertii Imperii (Língua do Terceiro Reich), e, numa estranha coerência com a obsessão dos nazistas por siglas, optou pela sigla LTI para simbolizar na sua perspectiva de linguista - o rebaixamento da língua alemã à condição de subserviência ideológica.

Surge assim, em 1947, seu livro LTI: Notizbuch eines Philologen, que, muito provavelmente por conter aspectos mais complexos e teóricos da análise da língua em particular e da linguagem de modo geral, não figurou entre as obras mais conhecidas da literatura do testemunho. De fato, esse é um livro sui generis, que ainda aguarda ser recebido também pelos teóricos da biopolítica e do biopoder, embora trabalhos escritos nas últimas duas décadas sobre a atualidade do pensamento judaico já reconheçam Klemperer como pioneiro e dono de análises atuais e perspicazes no que se refere ao estudo da linguagem totalitária ${ }^{11}$.

\footnotetext{
${ }^{10}$ Assim descrito por Klemperer: "Eu, que durante décadas exerci uma profissão prazerosa, acabei impregnado por ela, mais do que qualquer outra coisa. Agarrei firmemente a linguagem do Terceiro Reich, não em sentido figurado, mas literal e filológico. Essa minha vara de equilibrista me prestou enorme ajuda para suportar o vazio durante as dez horas de trabalho na fábrica, o pavor nas buscas domiciliares, as prisões, os maus-tratos.” (KLEMPERER, Victor. LTI: A linguagem do Terceiro Reich. Tradução de Miriam Bettina Paulina Oelsner. Rio de Janeiro: Contraponto, 2009, p. 49).

${ }^{11}$ Cf. ASCHHEIM, Steven E. Scholem, Arendt, Klemperer: Intimate Chronicles in Turbulent Times. Bloomington/Indianapolis: Indiana University Press, 2001, p. 70.
} 
Atualmente, na maioria das vezes em publicações de cunho jornalístico, a LTI é mencionada como língua oficial do nazismo. $\mathrm{Na}$ verdade há um pequeno equívoco nessa afirmação, pois a LTI nunca existiu oficialmente. Ela surge de um modo inusitado: a partir do uso novo e recorrente de certas palavras e expressões, a percepção do filólogo Klemperer - testemunha urbana dessas alterações - alia-se à tradição da suspeita filosófica e a reconstrói hipoteticamente como língua ocultada.

É possível traçar semelhanças entre o método de Klemperer e o método genealógico criado por Nietzsche nas suas investigações sobre a moral. Embora Klemperer não fosse um admirador de Nietzsche, o que poderia ser apresentado como ponto comum nesses dois pensadores além do fato de ambos serem filólogos - reside no fato de que seus métodos não estabelecem uma verdade no sentido epistêmico do termo. Eles se envolvem com o conhecimento de outra forma. Ao se irritarem intelectualmente como contemporâneos de determinada decadência social e cultural (especialmente o modelo de cultura no qual confiavam), posicionam-se na condição de designers hipotéticos da realidade concreta que teria originado essa decadência. Queriam pensar o momento da ruptura e do desvio sem recorrer a cacoetes metafísicos e ontológicos. São pensadores da crítica do tempo, para a qual a departamentalização do saber não consegue produzir abordagem compatível.

Como conceito, a LTI antecipa a Novilíngua, elemento literário criado por George Orwell que correspondia ao movimento de restrição da linguagem na sociedade distópica descrita em sua obra 1984, a qual se tornou referência incontestável nesse gênero literário ${ }^{12}$. A crítica a um totalitarismo pautado na exploração da linguagem - noção que Orwell desenvolveu de modo literário em 1948, publicou em 1949 e o notabilizou no pensamento contemporâneo (considere-se que a contemporaneidade assumiu em seu léxico o adjetivo orwelliano quando pretende lidar com o tema) - também fora desenvolvida, portanto, por Klemperer. Esta observação serve aqui apenas para ilustrar as diferentes mobilizações intelectuais no final da década de 40 a respeito do tema, uma vez que o fato de a LTI ter sido desenvolvida e publicada no mínimo dois anos antes

${ }^{12}$ Cf. ORWELL, George. 1984. Tradução de Wilson Velloso. $8^{\mathrm{a}}$ edição. São Paulo: Companhia Editora Nacional, 1975 . 
da Novilíngua não faz dela, por si só, um conceito mais consistente, bem como, de modo algum, deprecia esta última.

A consistência e importância da LTI têm a ver com as forças intelectuais que ela invoca, uma vez que um trabalho de tamanha envergadura exige uma erudição proficiente e sagaz para, na história das ideias, identificar o mecanismo das pequenas e das grandes farsas apresentadas pelo grandiloquente discurso nazista. A LTI é uma grande fábrica de signos, mas é necessário pertencer ao mundo intelectual para visualizar sua operacionalidade. Afinal, só a potência do pensamento desvela a farsa. Em decorrência disso, não é por mero acaso que, inspirado no fascismo, o nazismo se aprimorou na canalização de energia para combater o intelectualismo em todas as suas manifestações. Mas Klemperer - cuja sobrevivência pode ser ilustrada por uma sucessão de pequenos milagres - escapou à malha fina nazista; e teve fôlego e ajuda para anotar tudo.

Assim, o que torna potente e atual o trabalho de Klemperer se dá em mais de um nível intelectual. Em primeiro lugar, sua evidente capacidade técnica e teórica como estudioso da língua para analisar as palavras e expressões que compõem a LTI. Em segundo lugar, o plano reflexivo, histórico, político e filosófico da função dessas palavras e expressões dentro dos propósitos nazistas. Klemperer é um intelectual com uma capacidade ampla de contextualização aliada a uma fina sensibilidade, cuja identidade judaica (que ele não nega e nem afirma) se associa à formação germanista. A trajetória peculiar de Klemperer, influenciada pela projeção do ideal do século XIX em que se viveu na Alemanha o sonho de integrar germanismo e judaísmo, habilita-lhe a compor a eloquência negativa, em sentido dialético, da estrutura formal dos discursos nazistas. Por essa razão, a percepção só poderia surgir da perspectiva aguçada do que a LTI nega. Em termos psicanalíticos, esse movimento corresponderia à consideração daquilo que, embora recalcado pela linguagem, é já a própria constituição desta.

De outra forma, é possível pensar também que muitos humilhados foram esmagados pelos nazistas sem entender praticamente nada a respeito das motivações da humilhação sofrida. Klemperer, por sua vez, estava preparado intelectualmente para tentar entender a fundo os porquês de toda humilhação que sofreu, tendo a seu alcance, como base teórica e ponto de partida, a análise da linguagem. É obvio que entre as 
posições de entender os porquês e suportá-los emocionalmente há um abismo que não se deixa neutralizar por investigações filosóficas e científicas.

\title{
2 O prefixo ent [des] e seu potencial para sugerir hábitos
}

A primeira observação que Klemperer faz a respeito da LTI surge de um modo aparentemente despretensioso, mas que marca toda a trajetória da influência que a LTI exerceu sobre o cotidiano civil da sociedade alemã durante o domínio nazista. Eis então a primeira frase do prefácio dessa sua obra:

\begin{abstract}
Necessidades novas fizeram a linguagem do Terceiro Reich ampliar o uso do prefixo ent [des], que indica distanciamento; ele passou a ser acrescentado a alguns termos (se bem que, quando é usado, não se consegue saber se é um neologismo ou se a linguagem comum o tomou emprestado de expressões já conhecidas nos círculos especializados). ${ }^{13}$
\end{abstract}

Indicar distanciamento, bem como transmitir sua sensação, é uma funcionalidade geral do prefixo ent [des]. Para ilustrar essa funcionalidade, Klemperer usa dois exemplos completamente opostos da aplicação desse prefixo. O primeiro exemplo se refere ao período do regime nazista; o segundo, ao período pós-Segunda Guerra. A exposição se iniciará pelo segundo exemplo, contextualizando-o e apontando algumas breves limitações da abrangência funcional do distanciamento em sociedades que respeitam paradigmas democráticos. Depois, será abordado o uso do prefixo ent durante o período nazista.

\subsection{A estratégia do distanciamento em sociedades democráticas}

Com o final da Segunda Guerra os territórios onde o nazismo imperou foram inicialmente administrados pelos Aliados. Como em qualquer pós-guerra - mas considerando de modo especial a potência destrutiva desta - a necessidade de reconstrução dessas sociedades era urgente. É de senso comum que a reconstrução de uma sociedade deva passar essencialmente pelo revigoramento de sua economia. A esse

${ }^{13}$ KLEMPERER, 2009, p. 37. 
respeito, havia o fato consumado de que o nazismo liquidara a economia alemã, como diz Klemperer, levando "a Alemanha à bancarrota" ${ }^{14}$.

No entanto, a urgência em retomar a economia envolve o cotidiano das pessoas de uma forma nem sempre equilibrada. Tal retomada exige, obviamente, muito trabalho e dedicação por parte de seus cidadãos. Contudo, concentrados com excessiva boa vontade na vida prosaica do trabalho, é comum que se sejam negligenciados outros pontos também essenciais para a reconstrução de uma sociedade. O empenho no trabalho pode garantir a retomada da economia, mas não garante a recuperação de algo que fora dizimado pelos nazistas em sua própria sociedade: a plenitude da cidadania, uma vez que o nazismo relativizou a liberdade humana ao ponto de macular ideais consagrados da vida civilizada. A tese freudiana que vê o trabalho como repositório de sublimação ajuda a ilustrar a limitação que aqui se pretende apontar.

A nova vida cidadã a ser vivida deveria, portanto, surgir de um considerável investimento em dignidade, através da recomposição do imaginário por signos minimamente relevantes para a vida nessa sociedade que se pretendia restaurar. Para remover o mal causado pelos nazistas à sociedade, começava a ser pensada, então, a necessidade de promover processos de Entnazifizierung [des-nazificação], que foram observados por Klemperer na Alemanha ${ }^{15}$ :

Entnazifizierung é o nome que vem sendo dado ao esforço para livrá-la [a Alemanha] dessa doença fatal. Não desejo nem acredito que esta palavra hedionda possa perdurar muito tempo; assim que tiver cumprido a sua missão, desaparecerá e ficará somente na memória. ${ }^{16}$

A desnazificação é entendida, na sua condição de projeto político, como distanciamento dos ideais nazistas. É legítima sua expectativa de expurgar, de modo objetivo, as influências nazistas que aquela sociedade sofrera. Essa expectativa é coerente com as observações linguísticas

\footnotetext{
${ }^{14}$ Ibidem, p. 37.

${ }^{15}$ Embora Klemperer tenha vivido naquela que viria a ser a República Democrática Alemã (atualmente reunificada à República Federal da Alemanha), a divisão da Alemanha em dois Estados só viria a ocorrer em 1949, portanto, dois anos após a publicação da LTI. Por essa razão, Klemperer se refere simplesmente à Alemanha. Registre-se também que, mesmo não mencionado por Klemperer, os processos de desnazificação também seriam iniciados na Áustria que fora anexada à Alemanha de Hitler em março de 1938, o Anschluss.
}

${ }^{16}$ KLEMPERER, 2009, p. 37. 
apontadas por Klemperer de que o prefixo ent originalmente indica distanciamento.

Inicialmente esse distanciamento é pensado e aplicado como parte integrante do método usado para punir os responsáveis pelas atrocidades nazistas. Mas há uma fina contradição nessa estratégia do distanciamento. Como método, visava cumprir a expectativa ancestral que se deposita na punição, a saber, produzir um efeito catártico sobre a sociedade como um todo, o qual pudesse impelir moralmente aqueles que, porventura, ainda não se mostrassem suficientemente sensibilizados com as injustiças cometidas. Nesse contexto, o distanciamento se apresenta como prognóstico otimista de um porvir que ainda confiava no desgastado modelo punitivista para efetivação da justiça. Ou seja, tratava-se de um método que pretendia distanciar-se dos ideais nazistas, mas que se mostrava bem pouco distanciado de outros ideais compartilhados com os nazistas. Essa complexidade a respeito da crosta ideológica que envolve as medidas político-sociais a serem tomadas com o fim da Segunda Guerra foi observada por Theodor Adorno de modo aporético e desolador:

O pensamento de que após esta guerra a vida possa prosseguir "normalmente" ou que a civilização possa ser "reconstruída" - como se a reconstrução da civilização por si só já não fosse a negação desta - é uma idiotice. Milhões de judeus foram assassinados, e isso deve ser um mero entreato e não a própria catástrofe. O que afinal esta civilização ainda espera? E mesmo se a inúmeras pessoas ainda resta um tempo de espera, como imaginar que o que aconteceu na Europa não tenha consequências, que a quantidade de vítimas não se converta em uma nova qualidade de sociedade: a barbárie estará perpetuada. [...] Entretanto, se os mortos não forem vingados e não se usar a clemência, então o fascismo, deixado impune, é quem sai ganhando apesar de tudo, e uma vez que tiver mostrado como tudo foi fácil, recomeçará tudo em outros lugares. A lógica da história é tão destrutiva quanto os homens que ela engendra: para onde quer que tenda sua força de gravidade, ela reproduz o equivalente da calamidade passada. Normal é a morte.

À questão, o que se deve fazer com a Alemanha derrotada, eu só saberia responder duas coisas. Em primeiro lugar: em hipótese alguma e sob nenhuma condição eu desejaria ser carrasco ou fornecer legitimidade aos carrascos. Em segundo lugar: tampouco deteria a mão de alguém, menos ainda através do aparato jurídico, que se vinga pelo que aconteceu. Esta é uma resposta inteiramente insatisfatória, contraditória e que escarnece 
162 | Veritas | Porto Alegre, v. 63, n. 1, jan-mar. 2018, p. 150-189

tanto de sua generalização quanto da práxis. Mas talvez o erro já se encontre na questão e não em mim. ${ }^{17}$

É razoável que a nova sociedade não devesse herdar nada do cotidiano nazista. Mas há de se considerar a impossibilidade de (re)instaurar a normalidade, como atenta Adorno. Por outro lado, em bases democráticas, perdura, em discurso, a promoção do esclarecimento dos cidadãos, que envolve a ideologia da formação [Bildung $]^{18}$. Os discursos políticos de sociedades que se pretendem (ou se afirmam) livres pressupõem que seus cidadãos tenham amplo acesso, em seus sistemas de educação e informação, a referenciais teóricos e conteúdos compatíveis com as urgências que têm a enfrentar. Ou seja, uma real desnazificação dependeria da consciência que os cidadãos têm da necessidade dessa implementação e, a partir dessa conscientização, a disposição para assumir a responsabilidade por sistemas de educação e informação que contemplem uma larga tematização dos problemas instalados em sua sociedade ${ }^{19}$. Em outras palavras, não há como distanciar uma sociedade de seus males sem que isso seja antes um exercício pessoal e livre de seus cidadãos.

Trata-se, portanto, de um movimento que se inicia na condição de projeto político na medida em que visa erguer uma sociedade distanciando-a daquilo que ela havia se tornado, porém é extremamente dependente de elementos muito delicados quando se trata da promoção

${ }^{17}$ ADORNO, Theodor W. Minima moralia. Tradução de Luiz Educardo Bicca. $2^{\text {a }}$ edição. São Paulo: Ática, 1993, p. 47-48.

${ }^{18}$ Bildung em seu sentido original na língua alemã pode ser pensado como equivalente ao termo grego Paideia. Ambos podem ser compreendidos como projetos de construção de uma cultura civilizada e tramada a certos ideais que, eventualmente, apresentaram-se em determinados momentos históricos de modo relativizado, o que não compromete, obviamente, sua validade como projeto original.

${ }^{19}$ Pode-se pensar aqui também a respeito dos chamados processos de redemocratização de países da América Latina que viveram sob o domínio de governos violadores de direitos fundamentais nos anos 1960 e 70. Nesse sentido, a pretensão ideológica do prefixo re (muito semelhante ao des em questão), por exemplo, almeja uma mudança radical em um estado de coisas que parece bem mais acelerada do que os processos de conscientização da maioria dos cidadãos dessas sociedades, os quais muitas vezes tendem a acomodar seus imaginários em soluções políticas totalitárias, uma vez que as discussões sobre a recente história da ditadura ingressam de maneira muito tímida nos discursos de uma cidadania por vir. É claro que este é um círculo vicioso, pois em tempos de crise a demanda por conscientização concorre com outras demandas que também precisam se abrigar embaixo do grande guarda-chuva chamado Economia. No entanto, não será aprofundada aqui a corriqueira deslealdade dessa concorrência. 
do esclarecimento que, por sua vez, envolve a consideração de suas próprias limitações e armadilhas. A respeito do dilema que representa o processo de desnazificação como pretenso distanciamento, Jean Améry um sobrevivente de Auschwitz (e tantas outras prisões na Bélgica) que muito relutou em narrar suas vivências - escreveu décadas depois em um tom que mescla profecia e polêmica:

Um novo e, ao mesmo tempo, velho antissemitismo ergue atrevidamente
a cabeça ignóbil sem que provoque indignação - isso é verdade não só
para a Alemanha, mas para a maioria dos países europeus, com poucas
exceç̃es, entre elas a digna Holanda, cujo exemplo devo mencionar
explicitamente. As vítimas morrem, e é bom que assim seja, pois há muito
tornaram-se redundantes. Felizmente também desaparecem os carrascos,
atingidos pela lei da morte biológica. Mas em ambos os lados continuam
a nascer novas gerações. Entre uma e outra, todas marcadas pela origem
e pelo ambiente, volta a se abrir o velho abismo instransponível. Um belo
dia o tempo fechará. Mas o processo de maturação temporal não deveria
ser acelerado por uma reconciliação leviana, irrefletida,
fundamentalmente falsa. Ao contrário, como se trata de um abismo moral,
ele permanece aberto; também este é o sentido da reedição do meu texto. ${ }^{20}$

A despeito do sucesso ou do fracasso - que pertenciam às incertezas do porvir no momento da observação de Klemperer - do processo de desnazificação como distanciamento, havia uma ferida aberta: todas as características de uma democracia concreta foram aniquiladas durante o regime nazista e algo precisava ser feito. A desnazificação como providência democrática não é um problema em si mesmo, mas derivação de uma aporia da própria democracia, pois esta, enquanto pensada ideal e historicamente como abertura à complexidade dos fenômenos da liberdade e da realização humanas, respeita o esclarecimento de sua sociedade em tese, mas raramente o considera como uma demanda decisiva.

Klemperer não entrou diretamente nessa problematização, mas sua percepção sobre os usos do prefixo ent como pertencentes a estratégias do distanciamento pode ser considerada um insight para a discussão. Desse modo, pode-se pensar que a ideologia do bem-estar social é sempre uma intervenção biopolítica, pois a consciência esclarecida sabe que o bem-

${ }^{20}$ AMÉRY, Jean. Além do crime e castigo: tentativas de superação. Tradução de Marijane Lisboa. Rio de Janeiro: Contraponto, 2013, p. 18-19. 
164 | Veritas | Porto Alegre, v. 63, n. 1, jan-mar. 2018, p. 150-189

estar é uma condição que não pertence originalmente à natureza humana e que não pode ser oferecida de modo heterônomo, tal como as democracias da urgência prometem oferecer.

\subsection{A estratégia do distanciamento na sociedade nazificada}

O outro uso do prefixo ent apontado por Klemperer remete ao período nazista. Os nazistas tinham uma percepção diversa do distanciamento, que será aqui apresentada como contraste ao uso implícito do distanciamento nos processos democráticos de desnazificação. Um ponto essencial desse contraste deve ser demarcado de saída: enquanto o distanciamento com objetivos democráticos precisa ser considerado um movimento complexo, sob a influência do nazismo ele representa uma tarefa simples, de uso claro e preciso, justamente para não comprometer a instrumentalidade racional inerente à LTI. Assim, Klemperer relembra que durante o nazismo haviam aparecido algumas novas aplicações desse prefixo:

Quando havia o risco de bombardeio aéreo, as janelas das casas tinham de
ser escurecidas, no que resultava depois a incumbência diária de
entdunkeln [des-escurecer]. No caso de o teto pegar fogo, o sótão das casas
tinha de estar livre das tralhas habituais, para que as pessoas encarregadas
de apagar o incêndio pudessem agir; ou seja, o caminho tinha de estar
entrümpelt [des-entulhado]. Como era necessário encontrar novos
alimentos, a maneira de tirar o sabor amargo da castanha chamava-se
entbittern [des-amargar]... ${ }^{21}$

Enquanto no processo de desnazificação o distanciamento era considerado em relação a um mal essencial (a nazificação da sociedade), no período nazista o distanciamento consistia em uma sugestão de deslocamento de certos hábitos cotidianos. Ou seja, cada cidadão era desacomodado de sua rotina para em seguida ser reacomodado a ela. Esse ínterim entre ser desacomodado e reacomodar-se, espécie de sensação stand-by, era o alvo do distanciamento pretendido pelos nazistas. É claro que não foram os nazistas que inventaram o estado de prontidão comum aos tempos de guerra. Mas, em acordo com a funcionalidade de outra

${ }^{21}$ KLEMPERER, 2009, p. 37. 
expressão da LTI, a saber, prima organisiert [muito organizado] ${ }^{22}$, foi construída a ilusão de que a rotina originalmente tumultuada em um cotidiano de guerra poderia vir a ser organizada.

Mas por que essa sensação de stand-by era o alvo do distanciamento providenciado pela LTI? Primeiramente, porque os nazistas tinham o conhecimento de que essa sensação - típica do estado de prontidão na guerra - remete o ser humano à ancestral experiência do completo desamparo. Na expectativa de suprir essa angústia que constitui e molda a vida humana, a inteligência - como experiência individual e histórica - produz para o viver aquilo que se pode chamar de habitual, cujo sentido, aliás, está originalmente relacionado à etimologia do termo grego ethos ${ }^{23}$.

Ethos, nesse sentido, pode ser considerado a hipérbole do habitual, pois sua função na cultura é fomentar a possibilidade de que o cotidiano tenha como horizonte de realização sua contínua transformação em acomodação plena e satisfatória. A despeito disso, atrofia as disposições intelectuais dirigidas ao desamparo primordial, que é sempre trazido à superfície em tempos instáveis de modo concreto e desproporcional, o qual, solitariamente, o ser humano ou não sabe "organizar" ou se frustra quando tenta fazê-lo. De modo oportunista, como segundo movimento, o discurso nazista oferece amparo indireto a essa condição solitária ao distanciar os cidadãos do envolvimento na causa em questão. Os novos verbos desescurecer, desentulhar e desamargar, dentro de sua natureza semântica de ação, na condição de comando e orientação, visavam preencher a lacuna do desamparo ocupando-a operacionalmente. O distanciamento é então transfigurado em preenchimento do cotidiano da mencionada sensação de stand-by, mais precisamente - evitando o aprofundamento da experiência negativa da instabilidade provocada pelo

\footnotetext{
${ }^{22}$ Como observa Klemperer a partir de um pequeno diálogo que teve com um cidadão alemão no momento em que rumores de conquistas significativas dos Aliados começavam a circular. Na ocasião, o tal cidadão teria dito: "[...] eles têm de perceber que somos invencíveis e que não nos intimidam. Afinal, somos prima organisiert." De onde Klemperer conclui em pensamento: "Muito bem organizados - lá vinha de novo a expressão que parecia um narcótico, que alucinava o espírito daquela gente.” (KLEMPERER, 2009, p. 165.) Note-se também que Klemperer dedica um capítulo na LTI para tratar do espírito de organização dos alemães, intitulado "Sistema e organização".

${ }^{23}$ Note-se que aos judeus fora gradualmente negada a experiência do hábito (do habitual, do habitar), como já mencionado neste trabalho.
} 
166 | Veritas | Porto Alegre, v. 63, n. 1, jan-mar. 2018, p. 150-189

alarme de bombardeio aéreo ou qualquer outro risco iminente próprio da guerra.

Na perspectiva nazista, o sentido do distanciamento flerta com a sublimação, pois tem a ver com a manutenção de uma indiferença ininterrupta em relação à gravidade da realidade vivida naquele cotidiano. Como projeto biopolítico, o mascaramento da realidade era considerado providência fundamental, na medida em que os nazistas viam uma grande vantagem em manter o civil como útil ao regime. De momento lacunar de angústia, a prontidão se transformava em condição totalizante realizável para o indivíduo, pelo indivíduo e em nome do indivíduo. Como nota Klemperer: "Pois os nazistas, é claro, possuem um sistema de governo e sentem orgulho de que ele esteja na origem de cada manifestação e de cada situação de vida, razão pela qual Totalität é um dos pilares da LTI." ${ }^{24}$

O mascaramento da realidade simulava a plenitude da condição de conforto psicológico, para a qual Freud recorreu considerando o sentido dos termos alemães behagen [sentir-se protegido] e heimlich [familiar, habitual]. Esses termos foram notabilizados em duas das mais contundentes obras de Freud acrescidos do prefixo de negação un, sendo substantivados em Unbehagen [mal-estar] e Unheimlich [estranho, inquietante $]^{25}$. O propósito de Freud era ilustrar a condição humana que fora escancarada no século XX, o qual, com sua constelação de instabilidades, demandava o reposicionamento da perspectiva do ethos na cultura. Ao negar essa demanda de modo consciente e organizado, o nazismo pode ser pensado como o antagônico perfeito da psicanálise. Aliás, como para a razão nazista a psicanálise era considerada uma expressão do judaísmo - um jeito judeu de pensar -, merecia ser aniquilada como degeneração do pensamento ${ }^{26}$.

Embora Klemperer não demonstrasse conhecimento da psicanálise ou mesmo de Freud, as pistas para entender como a sociedade tinha sido nazificada mostra sintonia com a psicanálise, como por exemplo, na seguinte observação: "Não, eu não confio em considerações meramente

\footnotetext{
${ }^{24}$ KLEMPERER, 2009, p. 171.

${ }^{25}$ Cf. FREUD, Sigmund. O mal-estar na cultura. Tradução de Renato Zwick. Porto Alegre: L\&PM, 2010; FREUD, Sigmund. "O inquietante”. In: Obras completas (vol. 14). Tradução de Paulo César de Souza. São Paulo: Companhia das Letras, 2010.

${ }^{26}$ Note-se também a observação de Klemperer de que a LTI "[...] não pronuncia jamais a palavra filosofia, sempre substituída por Weltanschauung [visão de mundo].” (KLEMPERER, 2009, p. 170.)
} 
estéticas no que diz respeito à história das ideias, da literatura, da arte ou da linguagem. É necessário partir de posturas humanas básicas. Os meios de expressão podem ser iguais e almejar objetivos opostos." ${ }^{27}$

Klemperer testemunhou que o nazismo demonstrou entender de "posturas humanas básicas"; compreensão que pode ser aprofundada se contextualizada em relação à sua época. Entre os anos de 1939 e 1940 viveu-se o período conhecido como drôle de guerre [guerra de mentira], cuja atmosfera de incertezas impactava de um modo completamente novo a vida civil. Qualquer coisa poderia emergir a qualquer momento. Dado o contexto de qualquer guerra, o entendimento de que ela distancia toda a vida civil de seus hábitos cotidianos não é nenhuma novidade. Mas essa, definitivamente, não era uma guerra qualquer. A complexidade de seu desenrolar não cabia na memória de guerras já vividas. O empobrecimento de experiências, que Walter Benjamin notavelmente havia assinalado como característica nefasta da Primeira Guerra, apesar de todos os seus males ainda continha um suspiro humano, o qual o nazismo, inexoravelmente, trataria de sufocar na medida em que impunha uma narrativa oficial e totalizante. $\mathrm{O}$ discurso nazista, como narrativa oficial, era predador das narrativas periféricas, as quais demandam experiências singulares e intransferíveis. A linguagem totalitária se caracteriza como opressora na medida em que castiga ainda mais as nuanças já sofridas e massacradas da narrativa demandada da experiência individual $^{28}$.

Há de se pensar se outro tipo de guerra de mentira não teria ocupado todo o período entreguerras. E, sobretudo, se a intensidade com a qual fora vivida teria influenciado a subida de Hitler ao poder. Klemperer tem fortes indícios que baseiam uma reconexão dos fatos, capazes de ilustrar o êxito do discurso nazista. O uso pontual de termos aparentemente inofensivos na linguagem transforma a LTI em arsenal a serviço dos nazistas na sua guerra de mentira peculiar: a guerra de imaginários, antessala para a guerra concreta. Nesse jogo vil e

\footnotetext{
${ }^{27}$ KLEMPERER, 2009, p. 126.

${ }^{28}$ Para uma contextualização específica dessa abordagem benjaminiana, ver SANTOS, Marcelo Leandro dos. "El empobrecimento de las narrativas humanas en la contemporaneidade, a partir de una lectura de Walter Benjamin” in GONZÁLES, Diana M. Muñoz (editora). ¿El fin del hombre?: Humanismo y antihumanismo en la filosofía contemporánea. Tradução de Diana M. Muñoz Gonzáles. Bogotá: Editorial Bonaventuriana, 2016. (Colección humanismo y persona; 3), p. 51-71.
} 
inescrupuloso um simples prefixo outorgava, não apenas como metáfora, intrusão militar em atividades domésticas. Relembrando Celan: “[...] um homem mora na casa bole com cobras [...]"29. Por meio da LTI o domus fora sequestrado, tornando Hitler onipresente em cada lar alemão.

Assim, a pista inicial de Klemperer é contextualizada a partir de um sutil contraste entre a Alemanha nazista e a pós-nazista no uso de um mesmo prefixo. Ambas, ao inserirem na linguagem coloquial um uso até então inabitual do prefixo ent, sustentavam alguma expectativa de criar novos hábitos na vida comum daquela sociedade. Na primeira vez, como uma apropriação da LTI; na segunda, como providência democrática. Porém, a diferença essencial é de que, como uma esponja, o nazismo visava absorver a rotina da vida civil, sitiando-a por completo. Que a linguagem sirva politicamente é algo intrínseco à natureza política, mas a distinção de seus usos - suas intervenções e perversões - é tema biopolítico; perspectiva pela qual se quer aqui inscrever Klemperer como pensador negligenciado.

O distanciamento subentendido no uso do prefixo ent em verbos até então rotineiros é uma forma pela qual a LTI sugere à sociedade que ela se habitue ao inabitual. Ao aceitar essa obstrução (aparentemente pequena), o processo biopolítico de nazificação se instala, pois esta brecha inicial permite a entrada de sugestões maiores como, por exemplo, suportar o insuportável. Inicialmente essa argumentação poderia ser invalidada como reductio ad absurdum. No entanto, a cada nova e mais ampliada sugestão, o discurso nazista enaltecia a determinação civil de suportar um desafio ampliado.

Klemperer, ao concentrar-se em um apontamento sutil a respeito da prática nazista, faz com que a análise se potencialize justamente por sua falta de objetividade. É que, de modo inverso, a análise objetiva se concentra em dados universalizáveis. O dado mais universal sobre o nazismo (e que se torna seu emblema histórico) corresponde à sua indiscutível brutalidade. Mas essa consideração não permite que se pare para pensar nas sutilezas do nazismo. A sutileza não é uma característica do pragmatismo político, por mais democrático e bem intencionado que ele seja. Aliás, o próprio caráter de urgência do pós-Segunda Guerra não

\footnotetext{
${ }^{29}$ In GUINSBURG, J.; TAVARES, Z. (orgs.), 1969, p. 270-271.
} 
aceitaria que se dispensasse tempo para refletir sobre a face sutil do nazismo como pista para desnazificar a sociedade.

Do ponto de vista prático, a LTI usa o distanciamento para tornar a vida civil indiferente à natureza sombria do cotidiano. Pois se o cotidiano da guerra já é algo inabitual, essa dimensão era ampliada pela propaganda nazista que retratava a Alemanha como perseguida por tudo e todos, nublando as horas vividas com o medo ininterrupto de eventos catastróficos. Como gratificação exclusiva à fiel massa ariana, a LTI entranhada nos termos mais coloquiais - oferecia a neutralização dissolvendo o clima inabitual e inquietante. Mas esse é um tipo de oferta constituída pela confusão ancestral entre amor e sensação de exclusividade. A obscura política nazista falava o idioma do amor pervertido, o qual explora o medo alheio para oferecer em troca uma choupana de palha como guarida.

Uma vez aliviada, a população fortalecia a ilusão de que existia alguma técnica suficientemente capaz de suspender a instabilidade que estava instalada no seu dia-a-dia. Ao encontro disso, em discurso arrogante $^{30}$ - tal qual o discurso do pai poderoso - o governo nazista exibia-se como detentor dos meios técnicos capazes de suspender o perigo e prover estabilidade, dando sustentação idolátrica à crença popular de que se tratava de um governo eficiente, cujos métodos eram não apenas necessários, mas vitais. É claro que isso transformava o cotidiano em um ambiente propício para projetar anseios que se esgotavam nele mesmo. Se, por um lado, Klemperer se espanta: "Com que ingenuidade os tipos medíocres se adaptam ao ambiente!” ${ }^{1}$, por outro, mostra-se capaz de suspeitar que um ambiente pode ser distanciado linguisticamente de sua própria realidade, afastando-a de suas reais demandas intelectuais. A estratégia geral desse distanciamento, dissimulado pela LTI, ajudou a cultivar uma cidadania mediocrizada, refém do poder de modo semelhante a uma criança oprimida pela forma com que os adultos lhe oferecem afeto.

\footnotetext{
$3^{30}$ A arrogância está sendo aqui considerada como afeto que melhor corresponde à sensação de desamparo vivida pelas massas, na medida em que estabiliza o desconforto dessa sensação. Em linguagem nietzschiana, é como se a massa substituísse um envolvimento negativo por um afirmativo. Aliás, se estudada a fundo, toda a filosofia afirmativa de Nietzsche só se sustenta como movimento arrogante do espírito. Sobre esse tema, ver o primeiro capítulo de SANTOS, Marcelo Leandro dos. Constelação vital: da vida excitada à vida incitada um ensaio sobre o pensamento de Theodor W. Adorno. Tese de doutorado. Porto Alegre: PUCRS, 2010.
}

${ }^{31}$ KLEMPERER, 2009, p. 70. 
A aparente incógnita "Como foi possível o nazismo?" começa a perder seu véu na medida em que expõe as experiências às quais a massa envolvida no cotidiano da guerra fora submetida. De modo muito singular, certas misérias cotidianas bloquearam a percepção de que o veneno nazista já estava sendo experimentado pela língua, que é uma forma menos evidente de incorporar ideais e constituir ideologias. A LTI oferecia à vida cotidiana um esteio comum de aparente conforto psicológico. A grande contradição é que a mansidão resultante do conforto, em concreto, nem sequer condiz com o espírito tenso da guerra. Uma das formas de perceber isso é notando que havia uma desproporcionalidade entre a expectativa dos cidadãos alemães e os interesses reais de Hitler - do alto de sua personalidade megalômana - a respeito da guerra:

A partir da primavera de 1941, os bombardeiros de Hitler iriam diminuir suas incursões à Grã-Bretanha, porque, apesar da esperança de muitos alemães de que seu país, dominante na Europa, agora passaria a desfrutar a paz e a prosperidade, o Führer tinha outros planos para eles.

Hitler tinha em mente novas conquistas e, para tanto, precisava da força aérea. A Luftwaffe teria novos serviços na conquista de Grécia e Iugoslávia e, a partir do final de junho de 1941, nos vastos e traiçoeiros espaços da União Soviética, onde as batalhas engoliriam homens, tanques e aviões em um ritmo sem precedentes na história moderna. ${ }^{32}$

A arte de naturalizar a continuidade da guerra estava apoiada na exploração da linguagem. Como já aventado, os nazistas fizeram isso com a falsa simplicidade de procurar tornar habitual o que deveria ser inabitual. Assim, o ethos nazista apresenta-se também como a completa deformação [Unwesen] ${ }^{33}$ do sentido original de ethos, que remete a hábito, costume. Deformação suportada publicamente através de um uso equivocado da razão ao confundir o caráter emergencial, de natureza contingente, como algo fundamental. Klemperer, como poucos, conheceu de perto a rotina da nazificação da sociedade alemã, como ela evoluiu e tomou corpo, isto é, como ela incorporou o ethos deformado por Hitler. No entanto, essa observação não impede de considerar que a abrangência

\footnotetext{
${ }^{32}$ TAYLOR, Frederick. Dresden: Terça-feira, 13 de fevereiro de 1945. Tradução de Vítor Paolozzi. Rio de Janeiro: Record, 2011, p. 142.

${ }^{33}$ Para melhor compreensão do termo deformação, ver análise do termo Unwesen na obra Minima Moralia, de Theodor Adorno, aprofundada em SANTOS, 2010.
} 
do ethos constitui um problema diverso, a saber, o fato de que, do ponto de vista de suas intenções, ainda é um conceito historicamente superestimado pela tradição ocidental.

De modo um pouco distinto do que décadas depois Hannah Arendt investigou a respeito da banalidade do mal na análise do carrasco como homem comum, usual demais, habitual demais ${ }^{34}$, Klemperer já havia desenvolvido um questionamento semelhante, porém de um modo diverso. Sua questão consistia em entender como um cidadão qualquer, que não possuía um cargo oficial (para detrás dele se esconder, como teria feito Eichmann na análise de Arendt) se deixava nazificar. Em outras palavras, Klemperer avança para a seguinte questão: "Como foi possível transformar a vida comum em vida nazista?” E, em função das respostas produzidas, decepcionou-se profundamente com a cultura alemã, da qual era espiritualmente um devoto. Possivelmente em nome dessa devoção da segurança que ela lhe transmitia - inclusive resistira às oportunidades de deixar o país ainda no início do regime nazista, como fizeram alguns de seus familiares e amigos.

Aliás, as reflexões decorrentes de seu drama existencial o fazem reviver traços da sua ancestralidade judaica, que por alguns anos fora tida como influência arquivada no passado de sua história pessoal. Por esse prisma é interessante observar que uma análise do distanciamento se aplica também a Klemperer, uma vez que viveu por um período da sua vida como um distanciado do judaísmo em nome de ideais germânicos, os quais perderiam paulatinamente sua validade e seu sentido durante o nazismo. Este é um estranho testemunho de que a condição judaica lhe era indelével.

A respeito da necessidade de contextualização do surgimento das expressões referentes ao nazismo, Klemperer, na sua autoridade de filólogo, chama de testemunho fossilizado toda a situação em que alguma expressão torne a aparecer distanciada do contexto que a fez surgir. Sendo assim, a tendência é de que uma expressão somente:

[...] desaparecerá quando deixar de existir a situação a que se refere. Ainda levará tempo. Não apenas a ação nazista terá de desaparecer, mas também

\footnotetext{
${ }^{34}$ Cf. ARENDT, Hannah. Eichmann em Jerusalém: um relato sobre a banalidade do mal. Tradução de José Rubens Siqueira. São Paulo: Companhia das Letras, 1999.
} 
172 | Veritas | Porto Alegre, v. 63, n. 1, jan-mar. 2018, p. 150-189

a mentalidade nazista, o hábito de pensar nazista e justamente o seu solo mais fértil, a linguagem nazista. ${ }^{35}$

O comportamento acrítico em relação à realidade vivida é, nesse sentido, a desconexão dos contextos originalmente responsáveis por fazer surgir o próprio cotidiano de determinado indivíduo, tornando essa observação sobre o hábito de pensar nazista em um problema extremamente atual. Pois, quem vivencia apenas testemunhos fossilizados de seu cotidiano - na medida em que não suspeita do surgimento repentino de determinados termos em seu léxico - é alguém que, com maior facilidade, habitua-se aos resíduos fossilizados de sua própria cidadania. Esse risco perdura nas sociedades zumbis da atualidade pseudodemocrática, que em tempos de crise acentuam a sua espera por um médico-monstro que lhes dê feição. Tudo urge onde e quando a linguagem política extravia seu viço original e se deixa travestir de outras linguagens.

\section{Lacunas da formação no solo fértil da linguagem nazista}

Para entender como o nazismo conseguiu se estabelecer na condição de ethos é importante considerar que a observação de Klemperer de que a linguagem nazista seria solo fértil conta com a submissão da língua à instrumentalização. Consequentemente, a manipulação do imaginário fragilizado dos cidadãos alemães do período entreguerras se torna um projeto mais fácil de ser concretizado durante a Segunda Guerra, naquele momento ainda por vir. Se a linguagem nazista é o solo fértil que faz crescer a ação, a mentalidade e o hábito de pensar nazistas, o que caracteriza, então, sua fertilidade?

Uma pista deixada por Klemperer, nesse sentido, é de que o adubo para esse solo seria o testemunho fossilizado. Essa fossilização é exemplificada na contextualização da origem da palavra fascismo, tão influente para o ethos nazista e, portanto, algo que deveria ser de conhecimento geral de seus cidadãos:

[...] nessa época [1932] o termo já estava germanizado: escrevia-se

Faschismus com sch em vez de sc. Quatorze anos depois [1946], perguntei

${ }^{35}$ KLEMPERER, 2009, p. 38. 
a um aluno, durante a prova do Abitur, em uma escola de ciências humanas, o significado da palavra. Ele respondeu sem titubear: "Vem de fax, die Fackel [tocha].” Era um rapaz inteligente, devia ter sido membro da juventude hitlerista e com certeza coleciona selos. Conhece o emblema do fascismo italiano, que aparece nos selos da época de Mussolini: um feixe de varas com um machado no meio, que os lictores carregavam à frente de certos magistrados romanos. De mais a mais, ele já devia ter encontrado essa palavra em seus tantos anos de latim. Mas não conhecia o significado da palavra "fascismo". Os colegas ajudaram-no: "Vem de 'fascis' [feixe]". Quantos outros devem desconhecer o verdadeiro significado dessa palavra, se um estudante de ensino médio, educado no sistema nazista, não o conhece?... ${ }^{36}$

Klemperer observa que logo após o fim da Segunda Guerra havia muitas pessoas que sequer sabiam o significado de algo marcante do período recente de suas próprias vidas, uma vez que o fascismo fora cultuado pela sociedade nazista através de uma série de eventos promovidos pelo regime. Também a partir da lembrança de suas experiências da época em que ainda não havia perdido sua cátedra na Universidade - portanto, antes da Segunda Guerra -, Klemperer pode testemunhar:

[...] diversas vezes vi como jovens inocentes e sinceros se apegavam ao modo nazista de pensar para suprir erros e lacunas de sua formação, que deixava muito a desejar. Sem perceber, estavam confundidos e seduzidos pela linguagem de uma época que deixou de existir. Conversávamos sobre o sentido da cultura, humanismo, democracia. Algo me levava a crer que uma luz iria clarear essas mentes bem-intencionadas - mais eis que, de maneira natural e óbvia, algum aluno se referia ao comportamento heroico, à resistência heroica ou ao heroísmo em geral. Quando conceitos assim vinham à tona, dissipava-se a lucidez imaginada. Voltávamos ao nebuloso pensamento nazista. ${ }^{37}$

O envenenamento da linguagem explora sentimentos oriundos das mais diferentes carências humanas. Nisso consiste não apenas seu poder de sedução, mas, sobretudo, uma capacidade de amparar as ondas de diferentes direções e dar-lhes direção única em uma só maré. Para isso, os jovens se mostraram mais suscetíveis à arregimentação, o que se

\footnotetext{
${ }^{36}$ Ibidem, p. 101.

${ }^{37}$ Ibidem, p. 38, 39 .
} 
comprova na larga adesão aos movimentos da Juventude Hitlerista. Contribuiria para esse cenário o déficit da formação intelectual desses jovens, fato que foi muito bem percebido pelos nazistas e, em momentos precisos, inclusive estimulado. Baixa autoestima somada à formação precária ajudaram a adubar o terreno para uma recepção oportuna do discurso ideológico nazista.

Para desviar das questões referentes à má formação intelectual que deveria ser o foco para uma real reestruturação civilizada daquela sociedade saída como derrotada da Primeira Guerra - o nazismo enalteceu o sofrimento popular atribuindo-lhe, em discurso, um espírito heroico. Mas, como diz Klemperer, "[...] no verdadeiro hitlerismo, na comunidade dos hitlerianos, houve somente heroísmo externalizado, deformado, envenenado" ${ }^{38}$, que se expressava "[...] na ênfase dos elogios inúteis, nos assassinatos sem misericórdia..." 39 O que Klemperer critica "[...] no conceito nazista de heroísmo é que ele depende do aspecto promocional. Apresenta-se como soberba." ${ }^{\circ}$ Esse heroísmo promocional inflava a autoestima da juventude alemã, dissimulando o fato de que, na verdade, ela estava em baixa.

O modo condicionado pelo qual foi apresentado a essa geração o sentido do heroísmo foi construído ao lado do anti-intelectualismo. A uma juventude empobrecida de experiências e que não estava dirigida para a Bildung foi apresentado o heroísmo em "[...] três uniformes diferentes, sem jamais ter usado trajes civis" ${ }^{11}$. Klemperer se refere ao militar, ao piloto de automóvel de corrida e ao pugilista (o boxe era o esporte predileto de Hitler, mas a aura de glorificação do atleta se estendia a todos os desportistas), que foram muito celebrados no período nazista como modelos do herói ideal. "É impossível formar uma noção clara do verdadeiro sentido de humanismo, de cultura e de democracia se as pessoas pensarem dessa forma sobre o heroísmo, ou, para ser mais claro, se não refletirem sobre essa ideia" ${ }^{42}$, problematiza Klemperer. O heroísmo, que só faz sentido como experiência singular e intransferível, fora

\footnotetext{
${ }^{38}$ Ibidem, p. 45.

${ }^{39}$ Ibidem, p. 46.

${ }^{40}$ Ibidem, p. 44.

${ }^{41}$ Ibidem, p. 39.

${ }^{42}$ Ibidem, p. 39.
} 
mimetizado como programa de governo. Segue a definição do que Klemperer considerava como verdadeiro heroísmo, que consistia, em espírito, no completo oposto daquilo que era apresentado pelo ideal nazista:

O heroísmo é muito mais puro e significativo quanto mais discreto for, quanto menos público cultivar, quanto menores rendimentos trouxer para o próprio herói e quanto menos espalhafato alcançar. [...] O nazismo não conheceu oficialmente qualquer heroísmo honesto e autêntico. Ele o desvirtuou e o levou ao descrédito. 43

Uma vez que homens livres e felizes não teriam razão para desafiar heroicamente a realidade e o destino, falar em heroísmo é algo inabitual em sociedades civilizadas. Ele precisou, então, ser trazido pela propaganda, e, por meio dela, os nazistas souberam oferecer o heroísmo como popular e resultante de uma pedagogia do corpo. Numa estranha simbiose entre o militar, o atleta e aquele que desafia a velocidade dentro de uma máquina, sob o sopro mítico do herói, o hábito da coragem sofria exacerbação. Tudo era expresso no corpo individual e tendo esse conceito de corpo do povo como seu suprassumo:

Em Mein Kampf, Hitler, ao tratar de educação, coloca o preparo físico em primeiríssimo lugar. Sua expressão predileta é körpeliche Ertüchtigung [capacitação física], que ele tomou emprestada do léxico dos conservadores de Weimar. Ele valorizava o Exército do imperador Guilherme como a única organização saudável e vital de um Volkskörper [corpo do povo] apodrecido. Vê no serviço militar, sobretudo ou exclusivamente, uma educação para o desempenho físico. A formação do caráter é uma questão nitidamente menor: dominar o corpo é mais importante do que receber educação. Nesse programa pedagógico, a formação intelectual e seu conteúdo científico ficam por último, sendo admitidos a contragosto, com desconfiança e desprezo. A todo momento se expressa o temor diante do ser pensante e o ódio contra o pensar. ${ }^{44}$

A adulteração do sentido de heroísmo em “[...] exaltação dos alemães como raça eleita" 45 ultrapassava os limites do campo de batalha,

\footnotetext{
${ }^{43}$ Ibidem, p. 44.

${ }^{44}$ Ibidem, p. 39-40.

${ }^{45}$ Ibidem, p. 46.
} 
pois quando "[...] tudo é espetáculo bélico, o heroísmo militar pode ser encontrado em qualquer fábrica, em qualquer porão." ${ }^{46}$

O nazismo desvirtuou o sentido do heroísmo, distanciando também o sentido do adjetivo relativo à guerra, kriegerisch [guerreiro], que naquele momento, em função da necessidade de ampliação do engajamento civil e tendo a virtude da coragem distorcida por exagero, fora substituído por kämpferisch [combativo, agressivo, beligerante] que, por sua vez:

Reflete de maneira mais generalizada uma atitude de ânimo e de vontade que em qualquer circunstância visa à autoafirmação por meio de defesa e ataque, e não aceita renúncia. $\mathrm{O}$ abuso da palavra kämpferisch corresponde ao uso excessivo, errado e impróprio do conceito de heroísmo. ${ }^{47}$

Assim, sendo o Volkskörper [corpo do povo] ideologicamente conduzido e estimulado para a fúria autoafirmativa da vida civil (heroica e combativa), ele se revela um profundo antagonista da civilidade, a qual somente se pode construir a partir de tensões racionalizáveis e não como resultante imediata da autoafirmação. Por exemplo, a linguagem diz que democracia significa originalmente poder do povo; mas, que esse poder pressupõe o esforço da razão e disposição para todo o seu jogo de contradições é algo que não está simplesmente dito na palavra democracia. Qualquer compreensão não superficial de democracia é também expressão de que há algum domínio do sentido concreto de política, por mais frágil que seja essa compreensão inicial. Em função disso, a corrosão dos valores democráticos se torna, inevitavelmente, uma consequência lógica da exaltação da agressividade popular que, em ação eufórica voltada para a celebração de sua identidade, não vê vantagem alguma em dispensar tempo para a contradição e sua consequente mediação. $\mathrm{O}$ intelecto, nesse caso, poderia lhes roubar a verdade, que fora conquistada graças a uma postura de cegueira voluntária:

Atente-se para quantas vezes a palavra blindlings [cegamente] aparece nas declarações de fidelidade, nos telegramas e nos anúncios de homenagens e de participação nos doze anos do nacional-socialismo.

\footnotetext{
${ }^{46}$ Ibidem, p. 42.

${ }^{47}$ Ibidem, p. 42-43.
} 
Blindling, uma das palavras-chave da LTI, indica a condição ideal da mentalidade nazista em relação ao Führer e ao seu respectivo Unterführer [comandado]. [...] para executar uma ordem cegamente, não devo pensar sobre ela. $\mathrm{O}$ ato de pensar pode ensejar uma demora, um escrúpulo ou até mesmo estimular o senso crítico, levando à recusa à obediência. A essência da educação militar consiste em automatizar movimentos e atividades, de modo que o soldado e o grupo obedeçam à ordem superior sem passar por considerações de foro íntimo, independentemente de qualquer impulso instintivo, como se fossem máquinas que se põem em movimento quando acionadas por botões. ${ }^{4}$

Nesse processo de recusa do pensamento, o corpo do povo precisava ser cego. Note-se que Volkskörper surge para substituir a noção de sociedade alemã, mostrando-se, de fato, a palavra mais adequada para se referir a uma sociedade pueril, pois uma sociedade concreta seria justamente o oposto desta, na medida em que deveria investir na compreensão da profundidade de seus próprios problemas.

Klemperer percebe na política nazista a estratégia exploratória do substantivo Volk [povo], que foi elevado à condição de prefixo para vários outros termos cujo propósito era, por um lado, adular o espírito popular e, por outro, tornar natural a positividade e urgência de tudo que se associava a esse prefixo. Nesse sentido, sua versão adjetivada, völkisch, passou a ser usada em substituição a racial, com o intuito de apropriar-se da noção verossímil de que uma nação é feita de seu povo para em seguida deformá-la, com aplicação da tautologia, na noção inverossímil de que uma nação é feita de sua raça, fazendo ressurgir a identidade da Alemanha como pátria dos arianos, tal qual numa novela de terror o cientista idealista reanima o corpo morto ${ }^{49}$ :

A LTI insiste no aspecto emocional. [...] Desde o início foram tensas as relações entre o Führer e grupos nacionalistas que ele enxergava como concorrentes; mais tarde, quando não há mais por que temê-los, usa parcialmente seu conservadorismo e germanismo exacerbado. Da mesma forma, também espera poder contar com o apoio dos trabalhadores da indústria, pois o americanismo e a técnica não podem ser desprezados;

\footnotetext{
${ }^{48}$ Ibidem, p. 241-242.

${ }^{49}$ Embora a partir de diferentes fontes seja possível entender um pouco mais sobre o sucesso dessa estratégia política, Klemperer parece sempre estar inicialmente mais atento à percepção dos enunciados performativos nos atos de discurso, cuja teorização veio à tona uma década depois, com J. L. Austin.
} 
178 | Veritas | Porto Alegre, v. 63, n. 1, jan-mar. 2018, p. 150-189

mesmo assim, a glorificação do camponês apegado à terra, avesso a inovações, se manteve até o fim. A fórmula nazista Blubo foi cunhada para ele, ou melhor, extraída de seu modus vivendi..$^{\circ}$

Blubo, abreviatura para Blut und Boden [sangue e terra], é a criatura da política frankensteiniana de Hitler, que estiliza a figura do conservador como o tipo autêntico da totalidade alemã como povo que não permitia mais integrar-se com outras etnias, tal qual se havia tentado no século XIX. A isso se soma a apropriação de tudo que podia ser relativizado a povo [Volk] na condição de prefixo em várias palavras, as quais podem ser consideradas neologismos próprios do nazismo.

Apresenta-se aqui uma pequena lista de exemplos do uso de Volk como prefixo na LTI, já desmascarados de sua fachada conceitual: Volkssolidarität [solidariedade do povo] ${ }^{51}$, que de solidária não tinha nada, pois pressupunha a doação de si a um patriotismo fundamentalista em nome dos compatriotas que, aliás, também deveriam comungar da mesma doação; Volksgenosse [camarada do povo] ${ }^{52}$, membro da unidade mística da raça de sangue ariano - ou seja, não era uma ordem produzida pela razão; Volkswagen [carro do povo] ${ }^{53}$, projeto com a cara de Hitler, pois engajou a sociedade alemã (povo alemão desde um ângulo despolitizado) a investir na indústria do automóvel sob a promessa de que cada família seria proprietária de um veículo, coisa que nunca se concretizou uma vez que todo o investimento acabou sendo desviado para a construção de tanques de guerra; Volkssturm [milícia do povo] ${ }^{54}$, tropas militares criadas por decreto que recrutava homens civis entre 16 e 60 anos como oportunidade quase sagrada, pois através do sacrifício de si cada um poderia demonstrar a intensidade de seu patriotismo, cujo heroísmo assumia tonalidade mítica; Volksseele [alma do povo] ${ }^{55}$, apelo sentimental cujo espírito era composto de espontaneidade e instinto, características

\footnotetext{
${ }^{50}$ KLEMPERER, 2009, p. 361.

${ }^{51}$ Ibidem, p. 99.

$5^{2}$ Ibidem, p. 141-142.

${ }^{53}$ Ibidem, p. 147.

${ }^{54}$ Ibidem, p. 343.

${ }^{55}$ Ibidem, p. 360 .
} 
anti-dialéticas, por princípio; Volksgemeinschaft [comunidade do povo] ${ }^{56}$ sempre associada ao espírito do termo fanatisch [fanático]; volkhaft [próprio do povo] ${ }^{57}$, adjetivação da suposta autenticidade alemã, que permaneceria como parte de certa visão de mundo em alguns textos de Martin Heidegger e Karl Jaspers que se apoiam no conceito de autenticidade $^{58}$; volkstümlich [próprio dos hábitos do povo] ${ }^{59}$, que, se pensado a fundo, servia apenas para neutralizar a suspeita (já desenvolvida no presente texto) de que os hábitos do povo não passavam de mera sugestão do discurso nazista; volksnah [próximo do povo] ${ }^{60}$, esforço retórico que, entre outras aplicações, situava muito bem Hitler como alguém acessível ao povo, pois a transferência no falso pai onipresente nos lares alemães (também uma ideia vista neste texto) dissimulava a dimensão demagógica de seus discursos antissemitas, nos quais, por oposição, o judeu era visualizado, em função da distância de seus hábitos, como distante do povo, de sua comunidade, de sua alma, enfim, o Volksfremd [estranho ao povo, estrangeiro] ${ }^{61}$ - estratagema praticamente perfeito para transformar a xenofobia em disposição habitual daquela sociedade e constituinte de seu $e^{t h o s}{ }^{62}$.

Com o povo bem acomodado em seu falso pedestal, o ataque ao intelectualismo se tornaria um movimento praticamente natural:

\footnotetext{
${ }^{56}$ Ibidem, p. 363 e 367.

${ }^{57}$ Ibidem, p. 399.

${ }^{58}$ A respeito dessa associação, torna-se fundamental a leitura de ADORNO, Theodor W. "La jerga de la autencidad”. In Obra completa. Vol. 6. Tradução de Alfredo Brotons Muñoz. Madrid: Akal, 2005.

${ }^{59}$ KLEMPERER, 2009, p. 400.

${ }^{60}$ Ibidem, p. 410.

${ }^{61}$ Ibidem, p. 364 .

${ }^{62}$ Note-se as gradações que o judeu alemão enfrentou na sociedade nazista. Inicialmente, o estranhamento comum na perspectiva popular em função de tudo o que a diferença implica. Depois, considerado estrangeiro na própria pátria e, posteriormente, a perda da condição jurídica de sua cidadania. Avança ao ponto em que todas as contribuições judaicas na cultura alemã precisaram ser apagadas, pois não bastava aniquilar o judeu, ele ainda restava como fantasma, uma vez que para o imaginário nazista o judeu é eterno. Em função desta última consideração, pode-se destacar a seguinte observação de Klemperer sobre as patéticas providências nazistas: "O nome de Einstein [que era judeu alemão] desapareceu dos cursos de física, e a unidade de frequência, o hertz [homenagem ao físico Heinrich Herz, também judeu alemão], não podia mais ser designada com esse nome judaico." (KLEMPERER, 2009, p. 141.)
} 
[...] o próprio mestre da propaganda e da LTI [Klemperer refere-se a Goebbels], interessado no todo, soube desfazer a ligação original entre tradição e sentimento. Tanto para ele quanto para o Führer era óbvio que somente se conquista o povo pelos sentimentos. Was versteht so eine bürgerliche intellektuelle Seele vom Volk? [o que uma mente [sic] intelectual e burguesa entende do povo?], escreve em seus diários, intitulados Vom Kaiserhof zur Reichskanzlei [Da corte imperial à chancelaria] e revistos em detalhe, tendo em vista a publicação. A ligação imprescindível e repetida de todas as coisas, relacionamentos e pessoas com o povo [...], essa ligação se expressa em palavras que enfatizam o sentimento de um modo que soa hipócrita e despudorado. ${ }^{63}$

A admirada cultura alemã, seus movimentos históricos e seus representantes literários e do pensamento (ou seja, aquilo que originalmente poderia ser referido como tradição), fora, na percepção de Klemperer, neutralizada, pois “[...] no reino da LTI, a sentimentalização das coisas não implica de forma alguma retornar a qualquer tradição. Pode ligar-se livremente com o cotidiano, empregando expressões do lugarcomum ou neologismos aparentemente muito prosaicos" ${ }^{64}$. Aqui está implicada a pauperização da linguagem como uma forma de despotencializar a vida intelectual pela mesma técnica que retirou o viço original da política:

Embora o antissemitismo de Hitler corresponda a um sentimento básico, fundado no primitivismo intelectual, o Führer possui em igual medida, desde o início e no mais alto grau, aquela astúcia calculista que não parece se enquadrar nas características da pessoa incapaz, à qual ele muitas vezes é tão bem associado. Ele sabe que só pode esperar lealdade daqueles que estão no mesmo estágio de primitivismo. O método mais simples e seguro para mantê-los nesse estágio é alimentar, legitimar e glorificar o ódio instintivo contra o judeu. Aqui ele toca na parte mais fraca da mentalidade popular, pois há quanto tempo o judeu emergiu da segregação, do curral especial, para ser acolhido na comunidade nacional ${ }^{65}$

Em meio a tantos distanciamentos, a condição de Hitler como volksnah [próximo do povo] não poderia encontrar Leitmotiv mais consistente, pois, além dos afetos, partilha-se um mesmo inimigo. À

\footnotetext{
${ }^{63}$ KLEMPERER, 2009, p. 363-364.

${ }^{64}$ Ibidem, p. 366.

${ }^{65}$ Ibidem, p. 273.
} 
diferença dos intelectuais, ele entende o povo que, aliás, está dispensado de qualquer esforço intelectual para entender a si próprio:

Agora, o discurso ocupa uma posição mais importante, e sua essência
mudou. Dirigido a todos, não apenas a representantes do povo, precisa ser
compreensível a todos, isto é, precisa ser mais popular. O que é mais
popular é mais concreto. Quanto mais o discurso se dirige aos
sentimentos, quanto menos se dirige ao intelecto, mais popular ele é.
Quando deliberadamente começa a deixar de lado a inteligência,
entorpecendo-a, ultrapassa a fronteira e se transforma em demagogia ou
sedução. $^{66}$

No movimento contrário à promoção da intelectualidade, o discurso amplia-se para além da LTI como língua. O ideal da uniformização se torna visível e cotidiano quando os lugares de fala à multidão assumem a estética própria do nazismo, decorados com estandartes e bandeirolas ${ }^{67}$. Há a língua, mas há também a linguagem em sua totalidade a ser explorada pela incansável determinação nazista apoiada na figura de Hitler, empoderada pela fala e pela gesticulação. Esse ritmo violento de exploração pode ser entendido na prática da declamação, determinante na construção da imagem mítica de Hitler:

O domínio absoluto que esse pequeno grupo - ou melhor, que esse homem [Klemperer refere-se a Goebbels] - exerceu na normatização da linguagem se estendia por todo o âmbito da língua alemã, levando-se em conta que a LTI não fazia distinção entre linguagem oral e escrita. Para ela, tudo era discurso, arenga, alocução, invocação, incitamento. O estilo do ministro da Propaganda não distinguia a linguagem do discurso e a linguagem dos textos, razão pela qual era tão fácil declamá-los. Deklamieren [declamar] significa literalmente falar alto sem prestar atenção ao que se diz. Vociferar. O estilo obrigatório para todos era berrar como um agitador berra na multidão. ${ }^{68}$

São inúmeros os momentos nos quais Klemperer ilustra as propriedades cênicas do nazismo. A seguir, será apresentado o vício peculiar dessa técnica, que é, ao mesmo tempo, seu alvo e sua flecha: o fanatismo.

\footnotetext{
${ }^{66}$ Ibidem, p. 103.

${ }^{67}$ Cf. KLEMPERER, 2009, p. 103.

${ }^{68}$ KLEMPERER, 2009, p. 65 .
} 
182 | Veritas | Porto Alegre, v. 63, n. 1, jan-mar. 2018, p. 150-189

\section{A LTI como doutrina do fanatismo}

Não o entregueis à plebe entusiasta.

G. E. Lessing, em Natan, o Sábio

Klemperer afirma que "[...] a doutrina nazista acredita na estupidez das massas” ${ }^{69}$. Esta é, de fato, uma máxima compartilhada com muitos intérpretes não apenas do nazismo, mas dos sistemas totalitários, de modo geral. No entanto, dizer, por si só, que as massas são estúpidas, é uma observação insuficiente. Nesse sentido, Klemperer reconstrói a coerência dessa estupidez, fazendo notar que ela se dá à custa do esvaziamento do intelectualismo, e, em boa medida, da deterioração da Bildung. Além disso, demonstra como esse fenômeno ocorre associado ao enaltecimento de dimensões humanas ligadas à espontaneidade e ao instinto. As inteligências foram canalizadas para desviarem de qualquer mediação. Então, ao invés de se falar em estupidez ou burrice, pode-se falar em restrição do repertório de desafios intelectuais. Assim, não apenas soa mais elegante, mas, sobretudo, serve muito bem para tematizar como esse movimento passa necessariamente pela pauperização da linguagem. Em relação à pobreza da linguagem, Klemperer ressalta que "[...] a LTI é pobre, quer e tem de ser pobre, só se reforçando pela repetição. Martela sempre a mesma coisa." ${ }^{70}$ Por isso, o método é rudimentar, assim como seus apelos:

Ela [a LTI] não era pobre só porque todos se viam forçados a obedecer a um único padrão de linguagem, mas especialmente porque, por meio de uma limitação autoimposta, só permitia expor um lado da natureza humana.

Se puder se expressar com liberdade, qualquer língua consegue dar conta de todos os anseios humanos. Elas se prestam à razão e ao sentimento, são comunicação, diálogo e monólogo, oração e súplica, ordem e invocação. A LTI só se prestava à invocação. O tema podia ser da esfera pública ou privada - não, isso é falso, pois a LTI mal conhecia o domínio privado, confundindo-o com a esfera pública, assim como confundia as linguagens escrita e oral -, não importa, tudo era discurso e publicidade.

\footnotetext{
${ }^{69}$ Ibidem, p. 332.

${ }^{70}$ Ibidem, p. 395.
} 
“Tu não és nada, teu povo é tudo”, pregava. O que significa que nunca estás sozinho, contigo mesmo, nunca estás a sós com os teus, estás sempre exposto. $^{71}$

Esta passagem resume a conexão entre a pobreza da LTI e sua funcionalidade biopolítica de sequestro da intimidade, onde o domínio privado é substituído pela dominação do privado. Klemperer dá continuidade a esse raciocínio, acrescentando o aspecto do fanatismo:

A LTI pretende privar cada pessoa de sua individualidade, anestesiando as
personalidades, fazendo do indivíduo peça de um rebanho conduzido em
determinada direção, sem vontade e sem ideias próprias, tornando-o um
átomo de uma enorme pedra rolante. A LTI é a linguagem do fanatismo
de massas. Dirige-se ao indivíduo - não somente à sua vontade, mas
também ao seu pensamento - é doutrina, ensina os meios de fanatizar e as técnicas de sugestionar as massas. ${ }^{72}$

Seguindo a análise inicial do fenômeno do distanciamento, surge a questão: Como as peças são recolhidas de suas vidas próprias e acolhidas na vida comum? Há uma resposta para esse questionamento que pode ser produzida considerando-se o fanatismo como grande fio-condutor que sustenta a comunidade do povo [Volksgemeinschaft], afinal, a comunidade é o lugar da vida comum. A LTI é o idioma desse modelo de vida comum. "É evidente que a LTI, nos momentos culminantes, é uma linguagem de fé, já que visa ao fanatismo."73

Demandada pelo fanatismo, a individualidade, dissolvida na vacuidade do termo povo - preparado, por sua vez, para a vida comum como redundância desse vazio - através da propaganda, encontra estímulo e legitimação para exercer a política inconsciente, que é típica do engajamento das massas. Klemperer aponta certos elementos da LTI que se tornaram mais presentes como atividade civil. Entre eles, a absorção pela LTI do verbo diffamieren [difamar], estrangeirismo até então incomum na língua alemã, exerce papel essencial. O civil conhecia o verbo schlechtmachen [falar mal] e foi influenciado a intensificar seu sentido

\footnotetext{
${ }^{71}$ Ibidem, p. 65-66.

${ }^{72}$ Ibidem, p. 66.

${ }^{73}$ Ibidem, p. 185 .
} 
para a difamação, mais imponente segundo Klemperer ${ }^{74}$, como prática liberada de sua imoralidade original em "[...] lábios cheios de fé"75.

A LTI é tramada na escuridão do falso anonimato, muito bem ilustrado por Horkheimer e Adorno na astúcia da linguagem de Ulisses em seu diálogo com Polifemo ${ }^{76}$. Ninguém pronuncia. Ninguém difama. Ninguém é responsável. Com esse jogo, a linguagem se vê exorcizada de qualquer traço ético. É assim que o nazismo purifica a manifestação humana: desumanizando-a. Não se precisa mais prestar contas sobre o que se diz. Essa suspensão a LTI promoveu como mais um brinquedo para a massa ariana em relação aos judeus. Difamar o judeu - ou qualquer outro obstáculo para o Führer - era também ato lúdico e pedagógico. Pela análise da linguagem, Klemperer testemunhou e sentiu na pele que o judeu, em especial, estava condenado a viver o drama objetivo do homo sacer, conceito que mais tarde Giorgio Agamben recuperaria para contextualizar circunstância semelhante ${ }^{77}$, na medida em que não havia proteção jurídica alguma para o judeu contra praticamente nada, tampouco para a difamação.

Não há cultura do ódio sem difamação. O nazismo não existiria sem o discurso difamatório. A sociedade alemã não se nazificaria sem liberdade para difamar. Pode-se imaginar os estragos dessa prática por um tempo considerável sob o martelar da LTI. É certo que historicamente o judeu sempre foi alvo da difamação, mas na Alemanha nazista a humilhação diária do judeu é celebrada como continuum de uma doentia vitória eterna do povo alemão. Apoiado em práticas cotidianas como esta, o fanatismo se naturaliza na sociedade nazista:

Se, por longo tempo, alguém emprega o termo "fanático" no lugar de "heroico e virtuoso", ele acaba acreditando que um fanático é mesmo um herói virtuoso, e que sem fanatismo não é possível ser herói. As palavras fanático e fanatismo não foram criadas pelo Terceiro Reich, mas ele lhes adulterou o sentido; em um só dia elas eram empregadas mais do que em qualquer outra época. ${ }^{78}$

\footnotetext{
${ }^{74}$ Cf. KLEMPERER, 2009, p. 47.

${ }^{75}$ KLEMPERER, 2009, p. 108.

${ }^{76} \mathrm{Cf}$. HORKHEIMER; ADORNO, 1985.

${ }^{77}$ Cf. AGAMBEN, Giorgio. Homo Sacer: o poder soberano e a vida nua I. Tradução de Henrique Burigo. $2^{\text {a }}$ edição. Belo Horizonte: Ed. UFMG, 2010.

${ }^{78}$ KLEMPERER, 2009, p. 56.
} 
Fanático é o adjetivo elogioso que representa o momento supremo das qualidades do povo heroico e combativo. Klemperer elucida a origem do termo, a partir de observações de como o Iluminismo recriminava os termos fanático e fanatismo:

A raiz de fanático vem de fanum, santuário, templo. No início, o termo
significava pessoa em estado de êxtase, em êxtase religioso. Ora, os
iluministas lutavam conta tudo que pudesse perturbar a capacidade de
pensar. Sendo inimigos da Igreja, combatiam com rigor todo tipo de
superstição religiosa. Para eles, o fanático é, por excelência, inimigo dos
racionalistas. ${ }^{79}$

É nesse sentido que aquele que não cumpre certas exigências ou expectativas religiosas é considerado como posicionado "à frente do templo", literalmente em latim pro fanum [profano]. Não é difícil entender que, para o fanático, aquele que se impõe ao estabelecido é profano. A insistência na profanação é incompreensível para aquele que se situa no mundo como fanático. O nazismo laicizou a experiência do fanatismo religioso que, na tradição do pensamento, é degradante para o ser pensante. No entanto, como diz Klemperer, "[...] o nacional-socialismo se baseou no fanatismo e seu sistema de educação usou todos os meios possíveis para treinar para o fanatismo" ${ }^{80}$.

À medida que o nazismo avançava, o adjetivo fanático substituía o adjetivo apaixonado. "Onde antes se dizia ou escrevia leidenschaftlich [apaixonado], passou-se a dizer 'fanático'. Para que isso acontecesse foi necessário submeter o conceito a um certo enfraquecimento, uma espécie de banalização, uma perda de dignidade" ${ }^{81}$, complementa Klemperer.

Então, o fim da Segunda Guerra comprovaria o uso vergonhoso do termo, que já tinha no léxico um sentido pejorativo:

Um ano depois do colapso do Terceiro Reich é possível apresentar uma prova de que o termo fanatisch, palavra-chave do nazismo, nunca perdeu seu aspecto maléfico original, apesar do uso abusivo: enquanto por toda parte restos da LTI são assimilados pela linguagem atual, a palavra fanatisch desapareceu. O que nos permite concluir que, na consciência popular, a verdade se manteve viva: um estado de espírito confuso,

\footnotetext{
${ }^{79}$ Ibidem, p. 111-112.

${ }^{80}$ Ibidem, p. 115.

${ }^{81}$ Ibidem, p. 116.
} 
186 | Veritas | Porto Alegre, v. 63, n. 1, jan-mar. 2018, p. 150-189

próximo da doença e do crime, havia sido considerado como virtude suprema durante doze anos. ${ }^{82}$

Diante deste e de tantos outros exemplos do uso inescrupuloso da linguagem - de como ela foi distanciada de sua própria dignidade -, resta o questionamento de Klemperer: "Será que algum dia descobrirei alguma palavra honesta nesse regime?" ${ }_{3}$

\section{Considerações finais}

Aprende-se com a filosofia que produzir linguagem implica em constituir um mundo de sentido. A tradição ocidental do pensamento encontrou em suas origens gregas o termo para expressar essa expectativa humana de poder sobre a realidade: logos. No coração desse termo está imbricada a relação entre linguagem e pensamento como um só movimento. Uma vez permitido o enriquecimento da experiência da imbricação linguagem-pensamento (o logos constituído) a orientação mitológica não mais se sustentou como fonte principal de sentido. Esta é uma forma de entender as intenções salutares da tradição do pensamento como experiência. Se assim não fosse, esse tema não retornaria justamente nos momento de crise da cultura.

Victor Klemperer reconheceu a falsificação da tradição, identificando-a como esforço político do nazismo. O nazismo instalou sua própria língua na cultura. Como em toda instalação, lançou mão de meios técnicos, funcionais, semióticos, midiáticos etc. Dessa forma, a língua se ampliou para linguagem do mal. Essa farsa carecia de um nome próprio, e então LTI, dada a pobreza comum às siglas, parece ter lhe caído bem. Faz parte da dinâmica da LTI inibir a experiência do pensamento, afinal, toda reflexão é para ela um estorvo, uma perda de tempo se considerada a grandiosa luta em que estão todos empenhados. Klemperer percebeu o quanto e como a sociedade alemã lutou cotidianamente em nome do nazismo. Será que nós, hoje, também não lutamos irrefletidamente em nome de algo grande, poderoso e total?

\footnotetext{
${ }^{82}$ Ibidem, p. 117.

${ }^{83}$ Ibidem, p. 82.
} 
É muito provável que a estrutura - jogo implícito de relações - que deu funcionamento à LTI também funcione em outras plataformas. A linguagem empobrecida, como demonstrou Klemperer, é capaz de estimular os seres humanos ao engajamento operacional, cuja constituição é já expressão de uma hostilidade à reflexão. Será que a linguagem que temos usado cotidianamente não carrega em sua forma certa indiferença diante da presença de hábitos hostis? Talvez não, mas ela tem tantos traços de urgência, tão comuns à LTI...

Que seja, então, para nós, ao menos intrigante o esboço dessas semelhanças. É necessário desconfiar da língua que se instala repleta de boas intenções e praticidades, pois ela não vem sozinha. Para tudo há desdobramentos, consequências. Caso tal desconfiança faça sentido, cabe como esforço ético-reflexivo a reapropriação da linguagem através da reconsideração do jogo tensional - não mais em nome de uma grande ideia norteadora - mas em nome de sentidos extraviados ou esquecidos, os quais o entorpecimento do convívio social nos fez oprimir. Pois, afinal, muito antes dos dilemas biopolíticos que enfrentamos na atualidade, o nazismo já havia demonstrado força capaz de conseguir virtualizar o cotidiano, distanciando seus cidadãos de suas reais urgências.

\section{Referências}

ADORNO, Theodor W. "La jerga de la autencidad”. In: Obra completa. Vol. 6. Tradução de Alfredo Brotons Muñoz. Madrid: Akal, 2005. Ática, 1993.

AGAMBEN, Giorgio. Homo Sacer: o poder soberano e a vida nua I. Tradução de Henrique Burigo. $2^{\text {a }}$ edição. Belo Horizonte: Ed. UFMG, 2010.

AMÉRY, Jean. Além do crime e castigo: tentativas de superação. Tradução de Marijane Lisboa. Rio de Janeiro: Contraponto, 2013.

ARENDT, Hannah. Eichmann em Jerusalém: um relato sobre a banalidade do mal. Tradução de José Rubens Siqueira. São Paulo: Companhia das Letras, 1999.

ASCHHEIM, Steven E. Scholem, Arendt, Klemperer: Intimate Chronicles in Turbulent Times. Bloomington/Indianapolis: Indiana University Press, 2001. 
188 | Veritas | Porto Alegre, v. 63, n. 1, jan-mar. 2018, p. 150-189

FREUD, Sigmund. “O inquietante”. In: Obras completas (vol. 14). Tradução de Paulo César de Souza. São Paulo: Companhia das Letras, 2010.

. O mal-estar na cultura. Tradução de Renato Zwick. Porto Alegre: L\&PM, 2010.

GIRARD, René. O bode expiatório. Tradução de Ivo Storniolo. São Paulo: Paulus, 2004.

GUINSBURG, J.; TAVARES, Z. (orgs.). Quatro mil anos de poesia. Tradução de Modesto Carone. São Paulo: Perspectiva, 1969.

HORKHEIMER, Max; ADORNO, Theodor W. Dialética do esclarecimento. Tradução de Guido de Almeida. Rio de Janeiro: Jorge Zahar, 1985.

KLEMPERER, Victor. LTI: a linguagem do Terceiro Reich. Tradução de Miriam Bettina Paulina Oelsner. Rio de Janeiro: Contraponto, 2009.

LEVI, Primo. É isto um homem? Tradução de Luigi Del Re. Rio de Janeiro: Rocco, 1988.

NEGRI, Antonio. "El monstruo político. Vida desnuda y potencia” in: GIORGI, Gabriel; RODRÍGUEZ, Fermín (comps.). Ensayos sobre biopolítica: excesos de vida. Buenos Aires: Paidós, 2007, p. 93-139.

NESTROVSKI, Arthur; SELIGMANN-SILVA, Márcio (orgs.). Catástrofe e representação. São Paulo: Escuta, 2000.

ORWELL, George. 1984. Tradução de Wilson Velloso. $8^{a}$ edição. São Paulo: Companhia Editora Nacional, 1975 .

SANTOS, Marcelo Leandro dos. "El empobrecimento de las narrativas humanas en la contemporaneidade, a partir de una lectura de Walter Benjamin” in GONZÁLES, Diana M. Muñoz (editora). ¿El fin del hombre?: Humanismo y antihumanismo en la filosofía contemporánea. Bogotá: Editorial Bonaventuriana, 2016. (Colección humanismo y persona; 3), p. 51-71.

. "Primo Levi: escrever e sobreviver após Auschwitz". In: OLIVEIRA, Rejane Pivetta de (org.). Literatura para pensar e intervir no mundo. Porto Alegre: Ed. Uniritter, 2013, p. 125-147.

. Constelação vital: da vida excitada à vida incitada um ensaio sobre o pensamento de Theodor W. Adorno. Tese de doutorado. Porto Alegre: PUCRS, 2010.

TAYLOR, Frederick. Dresden: Terça-feira, 13 de fevereiro de 1945. Tradução de Vítor Paolozzi. Rio de Janeiro: Record, 2011. 


\section{Endereço postal:}

CCHS - Centro de Ciências Humanas e Sociais

Universidade do Vale do Taquari - Univates

Av. Avelino Talini, 171 Sala 202/2

95914-014 Lajeado, RS

Data de recebimento: 07/01/2018

Data de aceite: 11/03/2018 